\title{
Microfiltration: Effect of retentate protein concentration on limiting flux and serum protein removal with 4-mm-channel ceramic microfiltration membranes ${ }^{1}$
}

\author{
E. E. Hurt, M. C. Adams, and D. M. Barbano² \\ Northeast Dairy Foods Research Center, Department of Food Science, Cornell University, Ithaca, NY 14853
}

\section{ABSTRACT}

The objective of our study was to determine if the limiting flux and serum protein (SP) removal were different at 8, 9, or $10 \%$ true protein (TP) in the microfiltration (MF) retentate recirculation loop using $0.1-\mu \mathrm{m}$ ceramic graded permeability membranes with 4-mm-channel diameters operated at $50^{\circ} \mathrm{C}$ using a diluted milk protein concentrate with $85 \%$ protein on a total solids basis (MPC85) as the MF feed. The limiting flux for the MF of diluted MPC85 was determined at $3 \mathrm{TP}$ concentrations in the recirculation loop $(8,9$, and 10\%). The experiment was replicated 3 times for a total of 9 runs. On the morning of each run, MPC85 was diluted with reverse osmosis water to an MF feed $\mathrm{TP}$ concentration of $5.4 \%$. In all runs, the starting flux was $55 \mathrm{~kg} / \mathrm{m}^{2}$ per hour, the flux was increased in steps until the limiting flux was reached. The minimum flux increase was $10 \mathrm{~kg} / \mathrm{m}^{2}$ per hour. The limiting flux decreased as TP concentration in the recirculation loop increased. The limiting flux was $154 \pm 0.3,133 \pm 0.7$, and $117 \pm 3.3 \mathrm{~kg} / \mathrm{m}^{2}$ per hour at recirculation loop TP concentrations of $8.2 \pm 0.07,9.2 \pm 0.04$, and $10.2 \pm$ $0.09 \%$, respectively. No effect of recirculation loop TP concentration on the SP removal factor was detected. However, the SP removal factor decreased from 0.80 \pm 0.02 to $0.75 \pm 0.02$ as flux was increased from the starting flux of $55 \mathrm{~kg} / \mathrm{m}^{2}$ per hour to the limiting flux, with a similar decrease seen at all recirculation loop TP concentrations.

Key words: limiting flux, microfiltration, serum protein removal

\footnotetext{
Received October 28, 2014

Accepted January 3, 2015.

${ }^{1}$ Use of names, names of ingredients, and identification of specific models of equipment is for scientific clarity and does not constitute any endorsement of product by authors, Cornell University, or the Northeast Dairy Foods Research Center.

${ }^{2}$ Corresponding author: dmb37@cornell.edu
}

\section{INTRODUCTION}

\section{Micellar Casein Concentrate}

Microfiltration (MF) can be used to separate micellar CN from serum protein (SP) and other serum phase components in skim milk. The micellar $\mathrm{CN}$ is retained by the membrane, whereas SP passes through the membrane into the permeate. The retentate is a micellar CN concentrate (MCC), whereas the SP in the permeate can be further concentrated by UF to produce SP concentrates. The SP concentrates produced from the MF of skim milk have been found to have lower fat and NPN concentration when compared with whey protein concentrates (at equivalent protein concentrations) and better foaming and gelling properties (Luck et al., 2013).

The percent reduction in $\mathrm{SP}$ and other serum phase compounds, such as lactose and NPN, in the MCC depends on the process [number of stages, concentration factor $(\mathbf{C F})$, and diafiltration factor]. The MCC could have several commercial uses, including in cheese making to increase yield (Papadatos et al., 2003). Additionally, MCC could be used in the formulation of high-protein, shelf-stable beverages. The MCC has a lower concentration of heat-labile components, SP, and lactose, and has excellent heat stability under retort conditions (Sauer and Moraru, 2012).

\section{MF Feed}

If the target reduction (on a percent basis) in lactose is greater than the target SP reduction for the MCC, skim milk can be UF before MF to remove the extra lactose and reduce the required MF membrane area (Hurt and Barbano, 2015). The UF retentate will be a milk protein concentrate (MPC), which will have had a percentage of lactose, soluble minerals, and NPN removed and a true protein (TP) concentration greater than that of skim milk. The MPC are often classified based on their TP concentration, for example a MPC85 would be an MPC with $85 \% \mathrm{TP}$ on a TS basis. The US Trade Commission (2004) estimated global MPC 
production of 100,000 tonnes in 2002. Liquid MPC directly from a UF system could be diluted with water to a target TP concentration for use as an MF feed. The characteristics of an MF feed material might have an effect on MF system performance. Jimenez-Lopez et al. (2008) found that the aqueous phase minerals of milk played a role in membrane fouling. Less MF fouling was seen with lower concentrations of serum phase minerals.

\section{Gradient Permeability MF Membranes}

A variety of MF membranes can be used to separate micellar CN and SP. The research reported in the current paper will focus on the use of graded permeability (GP) ceramic membranes (manufactured by Pall Corporation, Cortland, NY). The membranes are available in configurations with 3- and 4-mm channel diameters. The GP membranes are tubular ceramic membranes that attempt to achieve a constant flux along the length of the membrane by building in a resistance gradient along the outside support layer of the membrane (Garcera and Toujas, 2002). The resistance gradient was designed for operation at a constant longitudinal pressure drop $(\boldsymbol{\Delta} \mathbf{P})$, and due to this constraint the MF system was operated at a constant $\Delta \mathrm{P}$ in the current study. When operating the system at a constant $\Delta \mathrm{P}$, the cross-flow velocity will depend on the density and viscosity of the retentate in the recirculation loop (Denn, 1980).

\section{Factors that Affect Limiting Flux}

The flux at which an MF process operates at will have an effect on the MF membrane area required to process a fixed mass of feed in a fixed time. Less membrane area will be required if the system operates at a higher flux (Hurt and Barbano, 2015). The limiting flux is the maximum flux that can be achieved by increasing the transmembrane pressure (TMP; Bacchin et al., 2006). A sustainable flux is a flux that the system can maintain for extended periods, such as for an entire production day. Once limiting flux has been determined, sustainable flux can be estimated.

Research on the MF of skim milk has found that limiting flux increases with increasing temperature and cross-flow velocity, whereas it decreases with recirculation loop TP concentration. Samuelsson et al. (1997) found that increasing both temperature and cross-flow velocity increased the limiting flux, with a limiting flux of $145 \mathrm{~L} / \mathrm{m}^{2}$ per hour at a temperature of $55^{\circ} \mathrm{C}$ and a cross-flow velocity of $8 \mathrm{~m} / \mathrm{s}$ (for the $\mathrm{MF}$ of skim milk with a recirculation loop TP concentration around 3.6\%). Samuelsson et al. (1997) also reported that the increase in limiting flux was proportional to the increase in cross-flow velocity. Gesan-Guiziou et al. (1999) also reported that the limiting flux increased as shear stress (cross-flow velocity) increased for the MF of skim milk (recirculation loop TP concentration around $5.8 \%$ ), with limiting fluxes in the 80 to $90 \mathrm{~L} / \mathrm{m}^{2}$ per hour range $\left(\right.$ at $50^{\circ} \mathrm{C}$ ). Increasing the concentration of $\mathrm{TP}$ in the recirculation loop is expected to decrease the limiting flux (Cheryan, 1998). Though not explicitly determining limiting flux, Vadi and Rizvi (2001) continuously concentrated skim milk and found that the flux decreased as the recirculation loop TP concentration increased (the flux decreased from $120 \mathrm{~kg} / \mathrm{m}^{2}$ per hour at a $\mathrm{CF}$ of $1 \times$ to $30 \mathrm{~kg} / \mathrm{m}^{2}$ per hour at $6 \times$ ).

\section{Limiting Flux and SP Passage Through the Membrane}

Zulewska et al. (2009) reported that, for the MF of skim milk (with a TP concentration in the recirculation loop of $8.3 \%$ ) using $0.1-\mu \mathrm{m}$ GP (4-mm channel diameter) membranes, SP passage through the membrane to be close to expected given that the concentration of $\mathrm{SP}$ in the permeate was similar to the concentration of SP in the feed (both 0.56\%), although SP passage was not corrected for any possible $\mathrm{CN}$ in the permeate. In the same experiment, using a uniform TMP system with $0.1-\mu \mathrm{m}$ ceramic membranes with $4-\mathrm{mm}$ channel diameters with a recirculation loop TP concentration of 8.7\%, Zulewska et al. (2009) found a similar SP removal to the GP system (64\% for the uniform TMP system compared with $61 \%$ for the GP system for a $3 \times \mathrm{CF}$ ). In Gesan-Guiziou et al. (1999), TP passage through the membrane decreased as flux increased and they found that the transmission of $\beta-\mathrm{LG}$ and $\alpha-\mathrm{LA}$ decreased to around $60 \%$ at the limiting flux compared with an initial transmission of $100 \%$. No systematic studies of the effect of protein concentration in the MF recirculation loop on limiting flux and SP removal have been reported. The objective of our study was to determine if the limiting flux and SP removal were different at 8 , 9 , or $10 \% \mathrm{TP}$ in the MF retentate recirculation loop using $0.1-\mu \mathrm{m}$ ceramic GP membranes with $4-\mathrm{mm}$ channel diameters operated at $50^{\circ} \mathrm{C}$ using a diluted MPC85 as the MF feed.

\section{MATERIALS AND METHODS}

\section{Experimental Design and Statistical Analysis}

The limiting flux for the MF of diluted MPC85 was determined at $3 \mathrm{TP}$ concentrations in the recirculation loop $(8,9$, and $10 \%)$ on $0.1-\mu \mathrm{m}$ GP membranes with 4 -mm channel diameters. The experiment was replicated 3 times for a total of 9 runs. On the morning 
of each run, MPC85 was diluted with reverse osmosis water to an MF feed TP concentration of $5.4 \%$. In all runs the starting flux was $55 \mathrm{~kg} / \mathrm{m}^{2}$ per hour and the flux was increased in steps until the limiting flux was reached. The minimum flux increase was $10 \mathrm{~kg} / \mathrm{m}^{2}$ per hour. Due to production scheduling of MPC85 supplied by O-AT-KA milk cooperative (Batavia, NY), the same batch of MPC85 was used in multiple replicates for the 4-mm channel diameter membranes [batch A was used for 1 run at $8 \%$ target TP and 2 runs at $10 \%$ target TP, batch $\mathrm{B}$ was used for the remainder of the runs (6)].

All data were analyzed by ANOVA using the Proc GLM (general linear model) procedure of SAS (SAS version 8.02, SAS Institute Inc., Cary, NC). The data was analyzed at the starting and limiting flux using a GLM where the dependent variable $=$ target $\mathrm{TP}+$ error. With target TP (a class variable with 3 levels: 8,9 , or $10 \%$ ) being the target TP concentration in the recirculation loop.

A split-plot model was used to determine the effect that recirculation loop TP concentration (whole plot categorical variable) and flux (starting and limiting; subplot categorical variable) on membrane performance. The GLM was dependent variable $=$ target $\mathrm{TP}$ + replicate $($ target $\mathrm{TP})+$ flux + target $\mathrm{TP} \times$ flux + error. The type III mean squares for replicate (target $\mathrm{TP}$ ) was used as the denominator in the F-test to test the significance of the whole-plot term (target TP). The type III mean square error for the model was used as the denominator in the F-test to test the significance of the subplot terms. Target TP was nested in replicate because there were only 2 different batches of MPC85 and that did not correspond to replicate. The effect of TMP on measured flux was determined using the following GLM: measured flux $=$ target $\mathrm{TP}+$ replicate $($ target $\mathrm{TP})+\mathrm{TMP}+\mathrm{TMP} \times$ target $\mathrm{TP}+\mathrm{TMP} \times$ replicate $($ target $\mathrm{TP})+\mathrm{TMP} \times \mathrm{TMP}+\mathrm{TMP} \times \mathrm{TMP}$ $\times$ target $\mathrm{TP}+\mathrm{TMP} \times \mathrm{TMP} \times$ replicate $($ target $\mathrm{TP})$, where TMP was a mean-centered continuous variable.

\section{Preparation of MF Feed}

The MF feed was an MPC85 with $85.5 \pm 0.3 \%$ TP on a TS basis, provided by O-AT-KA Milk Products Cooperative Inc. Liquid MPC85 at approximately $12.34 \pm$ $0.04 \%$ TP determined using an infrared (IR) spectrophotometer (Milkoscan, Foss, Hillerød, Denmark) was stored at $<4^{\circ} \mathrm{C}$ until use. On each day MPC85 (325 \pm 2 $\mathrm{kg}$ ) was diluted to $5.4 \% \mathrm{TP}$ as determined with by IR, with hot reverse osmosis water $\left(390 \pm 4 \mathrm{~kg} ; 70^{\circ} \mathrm{C}\right)$ in a separate jacketed MF product feed tank. The diluted MPC85 was brought to a final temperature of $50^{\circ} \mathrm{C}$ in the MF product feed tank.

\section{MF System}

A $0.1-\mu \mathrm{m}$ ceramic GP Membralox module with $4 \mathrm{~mm}$ channel diameters (7 sticks with 19 channels per stick and a membrane area of $1.7 \mathrm{~m}^{2}$; EP1940GL0.1 $\mathrm{A}$, Alumina, Pall Corp.) was used in our study. A pilot MF system was used, shown in Figure 1 (Model CF 1000, Pall Corp.), which consisted of a 7.5-hp feed pump (LKH 10, Alpha Laval, Lund, Sweden) that determined the pressure at the outlet end of the membrane on the retentate side (Pro) and a 20-hp recirculation pump (LKH25, Alpha Laval) that determined the $\Delta \mathrm{P}$ (Pro-Pri). The location of the 3 pressure measurements are shown in Figure 1, the pressures were determined using pressure transmitters (Cerabar M-PMP, Endress+Hauser, Greenwood, IN). Electromagnetic flow meters were used to measure the recirculation rate (Promag 53, Endress+Hauser) and permeate and retentate removal rates (Promag H, Endress+Hauser). The permeate and retentate removal rates were controlled by air-actuated diaphragm valves (Gemu Type 650, Atlanta, GA). The MF rig also contained an onboard feed tank (350 L). The chilled water flow rate, feeding a shell and tube heat exchanger (Enerquip LLC., Medford, WI) on the recirculation loop, was used to control the temperature of the system.

The flux, CF, $\Delta \mathrm{P}$, and outlet pressure on the retentate side (Pro) were controlled during the run by an onboard computer (1500P, Allen-Bradley, Milwaukee, WI). The flux was controlled by opening and closing the permeate removal valve. The CF was controlled by opening and closing the retentate removal valve. The $\Delta \mathrm{P}$ was controlled by increasing or decreasing the recirculation pump speed, and the retentate outlet pressure (Pro) was controlled by modifying the feed pump speed. The TMP was calculated as the average of the pressure at the inlet and outlet end of the membrane on the retentate side minus the permeate pressure at the outlet end of the membrane $[($ Pro + Pri $) / 2$ - permeate pressure].

\section{MF Cleaning}

Immediately after each run the MF system was cleaned. The system was rinsed with approximately $350 \mathrm{~L}$ of water $\left(30^{\circ} \mathrm{C}\right)$. The retentate removal rate was approximately $600 \mathrm{~L} / \mathrm{h}$ and the permeate removal rate was approximately $180 \mathrm{~L} / \mathrm{h}$ during the rinse. After the system was rinsed, the fouled water flux was measured as follows: the recirculation pump was turned off and the retentate valve was completely shut, the permeate valve was then opened to $95 \%$, and the permeate removal rate was recorded as well as the pressures at the retentate inlet and outlet (Pri, Pro) and the permeate 


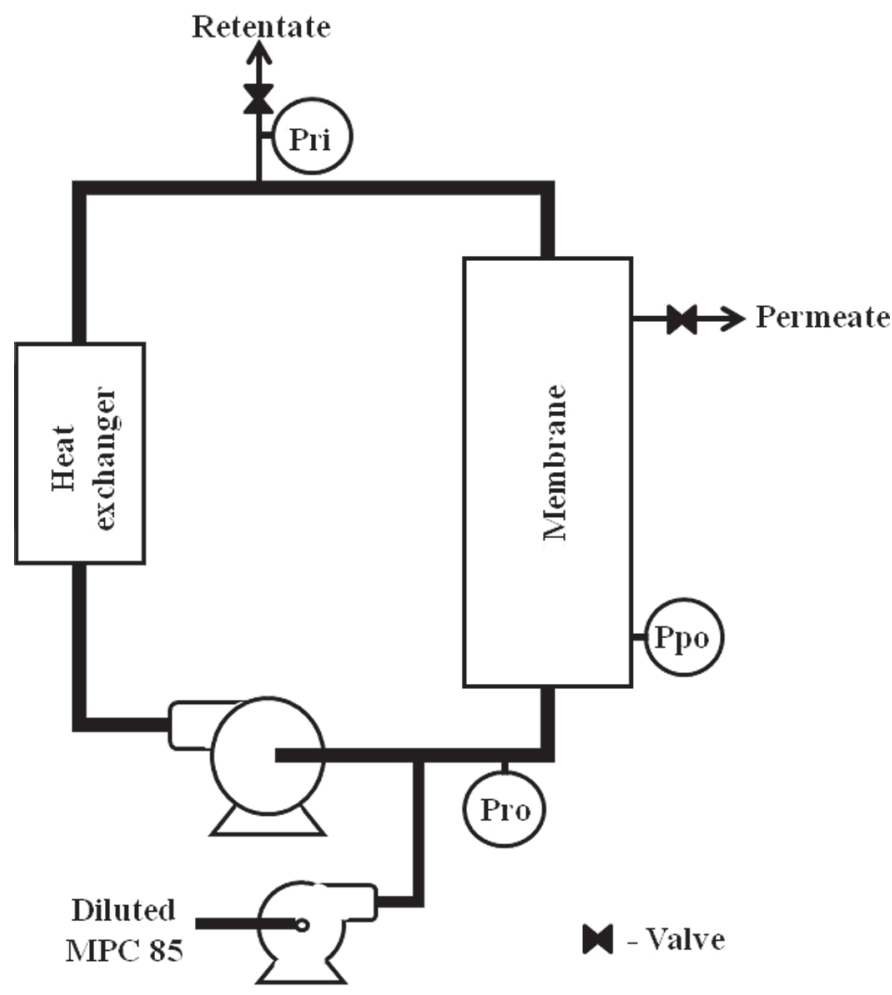

Figure 1. Diagram of the pilot microfiltration unit showing the location of the pressure measurements. Pressure on the inlet end of the membrane on the retentate side (Pri), pressure on the outlet end of the membrane on the retentate side (Pro), and pressure on the outlet end of the membrane on the permeate side (Ppo).

pressure. After the fouled water flux was measured, the recirculation pump was turned on and the retentate valve opened, and the permeate valve was set to a removal rate of approximately $180 \mathrm{~L} / \mathrm{h}$. Twelve liters of an alkaline membrane cleaner, Ultrasil 25 (Ecolab Inc., St Paul, MN), was added to the clean-in-place (CIP) feed tank filled with $320 \mathrm{~L}$ of water $(3.75 \% \mathrm{vol} /$ vol). The alkaline cleaner was recirculated at $50^{\circ} \mathrm{C}$ for 30 min. In previous research (Zulewska et al., 2009), the caustic clean took place at $80^{\circ} \mathrm{C}$, whereas in this work a mechanical issue meant that we were not able to produce $80^{\circ} \mathrm{C}$ hot water for the caustic clean and the cleaning step took place at $50^{\circ} \mathrm{C}$. After $30 \mathrm{~min}$, the system was rinsed with approximately $350 \mathrm{~L}$ of water $\left(50^{\circ} \mathrm{C}\right)$. The clean water flux was measured $\left(50^{\circ} \mathrm{C}\right)$ after the rinse using the same method used to determine the fouled water flux. After the clean water flux, the recirculation pump was turned on, the retentate valve was opened, and $12 \mathrm{~L}$ of acid membrane cleaner (Ultrasil 76, Ecolab Inc.) was added to the CIP tank filled with $320 \mathrm{~L}$ of water $(3.75 \% \mathrm{vol} / \mathrm{vol})$. The acid was recirculated at $50^{\circ} \mathrm{C}$ for $10 \mathrm{~min}$. The MF system was stored in this acid solution until the next run.

\section{MF Operation}

On the day of the processing run, the MF membranes that had been stored in acid overnight were rinsed with approximately $400 \mathrm{~L}$ of water at approximately $50^{\circ} \mathrm{C}$. The CIP tank was then filled with water and the system was allowed to heat up to $50^{\circ} \mathrm{C}$ by recirculating the retentate and permeate back into the CIP tank. When the system was at $50^{\circ} \mathrm{C}$, the clean water flux was measured using the method described previously. The average clean water flux for the 4 -mm membranes was $363 \pm 1 \mathrm{~kg} / \mathrm{m}^{2}$ per hour. After the clean water flux was measured, the feed pump was set so that the pressure at the outlet end of the membrane on the retentate side (Pro) was $230 \mathrm{kPa}$. The recirculation rate was then increased by increasing the recirculation pump speed until the $\Delta \mathrm{P}$ was $220 \mathrm{kPa}$. The permeate removal rate was set to achieve a flux of $55 \mathrm{~kg} / \mathrm{m}^{2}$ per hour and the retentate removal rate was set to achieve the target $\mathrm{CF}$ (approximately 1.6, 1.8, and $2.0 \times$ for target recirculation loop TP concentrations of 8,9 , and $10 \%$, respectively).

Startup. After the system was heated to $50^{\circ} \mathrm{C}$ and the flux and CF were set, the valve from the CIP tank (containing water) was closed and the valve to the MF product feed tank (with the diluted MPC85) was simultaneously opened. To flush the system, approximately $302 \pm 12 \mathrm{~kg}$ of permeate and retentate were collected, weighed, and discarded. Once the concentration of TP in the retentate was within $10 \%$ of the target $\mathrm{TP}$ concentration as determined by IR analysis of the retentate, the retentate and permeate were recycled to the MF product feed tank.

Determination of the Limiting Flux. After the retentate and permeate were recycled to the MF product feed tank, the system was operated at a flux of $55 \mathrm{~kg} / \mathrm{m}^{2}$ per hour for $1 \mathrm{~h}$. Permeate and retentate removal rates were measured by weight every $15 \mathrm{~min}$. Pressures, temperature, and the recirculation rate were also recorded every $15 \mathrm{~min}$. After $1 \mathrm{~h}$ at $55 \mathrm{~kg} / \mathrm{m}^{2}$ per hour the flux was increased. The flux steps are shown in Table 1 and depended on the retentate TP concentration. The flux was increased in steps with a 1-h stabilization period after each increase. At some point the target flux could not be achieved and further increasing the TMP did not lead to an increase in flux. The limiting flux was taken as the last flux that the system was able to operate in a stable manner (constant TMP) for $1 \mathrm{~h}$. The goal was to have each run last approximately $5 \mathrm{~h}$ and to have the target fluxes spaced closer together as the limiting flux was approached.

Samples of retentate and permeate were taken after the 1-h stabilization period at each flux and frozen for 
Table 1. Target fluxes for the 8,9 , and $10 \%$ retentate true protein (TP) concentrations on the 4-mm channel diameter ceramic graded permeability membranes when using diluted $85 \%$ milk protein concentrate as a feed

\begin{tabular}{lrrrrrr}
\hline $\begin{array}{l}\text { Target TP } \\
\text { concentration }\end{array}$ & \multicolumn{5}{c}{ Target flux $\left(\mathrm{kg} / \mathrm{m}^{2}\right.$ per h) } \\
\hline $8 \%$ & 55 & 85 & 115 & 145 & 155 & 165 \\
$9 \%$ & 55 & 85 & 115 & 125 & 135 & 145 \\
$10 \%$ & 55 & 85 & 95 & 105 & 115 & 125 \\
\hline
\end{tabular}

later chemical analysis. The TP concentration of the retentate and permeates was monitored during the run by IR analysis every $15 \mathrm{~min}$. Based on the results from the IR, the $\mathrm{CF}$ was adjusted to maintain the target $\mathrm{TP}$ concentration.

\section{Chemical Analyses}

A sample of the MF feed (diluted MPC85) was taken before each run and samples of the permeate and retentate were taken after $1 \mathrm{~h}$ at each flux. The samples were frozen $\left(-40^{\circ} \mathrm{C}\right)$ until analysis. The MF feed (diluted MPC85) was analyzed for TS, fat, and lactose using forced-air oven drying (AOAC International, 2000; method 990.20; 33.2.44), ether extraction (AOAC International, 2000; method 989.05; 33.2.26), and enzymatic lactose (AOAC International, 2000; method 984.15; 33.2.67, Lynch et al. 2007), respectively. The diluted MPC85, retentates, and permeates were analyzed for total nitrogen (TN) and NPN by Kjeldahl (AOAC International, 2000; method 991.20; 33.2.11) and (AOAC International, 2000; method 991.21; 33.2.12), respectively. Noncasein nitrogen content of the diluted MPC85 was determined using Kjeldahl (AOAC International, 2000; method 998.05; 33.2.64), modified by using $5.5 \mathrm{~mL}$ of acetic acid (10\% vol/vol) and $5.5 \mathrm{~mL}$ of sodium acetate $(1 N)$ instead of $1 \mathrm{~mL}$ of each, to ensure that a final filtrate $\mathrm{pH}$ of less than 4.6 was achieved and that all of the $\mathrm{CN}$ was precipitated. Total protein was calculated by subtracting NPN from TN and multiplying by 6.38 , CN was calculated by subtracting the NCN from TN and multiplying by 6.38 , and SP content was calculated by subtracting NPN from NCN and multiplying by 6.38 .

Viscosity of the retentates was measured at each flux step. The viscosity was measured at $50^{\circ} \mathrm{C}$ using a Brookfield viscometer (model DV2TLVTJO) with a ultralow adapter for low-viscosity fluids (Brookfield Engineering Laboratories, Inc., Middleboro, MA). A water bath was heated to $50^{\circ} \mathrm{C}$ and this water was recirculated through the jacketed sample cup using a peristaltic pump. The retentate samples were heated in a water bath at $50^{\circ} \mathrm{C}$ and then approximately 16
$\mathrm{mL}$ was placed in the sample cup. The viscosity was measured at $60 \mathrm{rpm}$ (shear rate of $731 / \mathrm{s}$ ) for $50 \mathrm{~s}$. The recorded viscosity was the average viscosity measured in $\mathrm{Pa} \times \mathrm{s}$ during the last $30 \mathrm{~s}$ of the measurement.

\section{Calculation of the SP Removal Factor}

The SP removal factor was the ratio of SP removed in the permeate to the theoretical SP removal. An SP removal factor of 1 would mean that the membrane was not rejecting any SP. Theoretical SP removal (in $\mathrm{kg}$ ) was equal to the mass of permeate multiplied by the concentration of SP in the permeate portion of the MF feed. The concentration of SP in the permeate portion of the MF feed was the mass of SP in the feed divided by the mass of feed less the mass of $\mathrm{CN}$ in the feed. The actual SP removed in the permeate (in $\mathrm{kg}$ ) was the mass of permeate multiplied by the concentration of TP in the permeate. It was assumed that all of the TP in the permeate was SP. Because mass of permeate appears in both the numerator and denominator, the SP removal factor was independent of permeate mass.

\section{RESULTS}

\section{MF Feed Composition}

The average composition of the diluted MPC85 used as the MF feed is shown in Table 2 for each target TP concentration. Because the MPC85 was produced using UF with diafiltration to remove a large portion of the lactose and NPN, the concentration of these components in the diluted MPC85 was lower than in skim milk (typical skim milk anhydrous lactose concentration: $4.75 \%$; NPN $\times 6.38: 0.18 \%)$.

The MPC85 $(12.35 \% \mathrm{TP})$ was diluted with reverse osmosis water to produce an MF feed with $5.4 \% \mathrm{TP}$ as determined using IR analysis calibrated for testing milk in the range of 2 to $4.5 \%$ TP. As shown in Table 2 , the TP concentration measured by Kjeldahl was higher than $5.4 \%$, but no difference among the 3 different target TP concentrations was detected $(P>0.05)$. Casein as a percentage of TP is shown in Table 2. A trend $(P=0.06)$ toward a higher $\mathrm{CN}$ as a percentage of TP was observed in the diluted MPC85 compared with samples of pasteurized milk taken from the same production facility, which had an average $(\mathrm{n}=3) \mathrm{CN}$ as a percentage of $\mathrm{TP}$ of $82.7 \pm 0.4 \%$. It is possible that the slightly higher $\mathrm{CN}$ as a percentage of $\mathrm{TP}$ in the MF feed was due to some SP being lost during the UF process. Barbano et al. (1988) reported that UF of whole milk produced permeate with a TP concentration in the permeate of $0.25 \mathrm{~g} / \mathrm{L}$ (most of which was $\alpha-\mathrm{LA}$ ). 
Table 2. Mean $(\mathrm{n}=3)$ composition of the diluted $85 \%$ milk protein concentrates used as the microfiltration feed for the 3 target recirculation loop true protein (TP) concentrations (percent by weight) ${ }^{1}$

\begin{tabular}{|c|c|c|c|c|c|c|c|c|c|c|}
\hline $\begin{array}{l}\text { Target TP } \\
\text { concentration }\end{array}$ & \multicolumn{10}{|c|}{ Microfiltration feed composition ${ }^{2}$} \\
\hline $8 \%$ & 6.48 & 0.24 & 0.08 & 5.56 & 0.03 & 0.92 & 5.53 & 0.89 & 4.65 & 83.96 \\
\hline $10 \%$ & 6.43 & 0.26 & 0.08 & 5.50 & 0.03 & 0.94 & 5.47 & 0.90 & 4.57 & 83.49 \\
\hline $\mathrm{SE}$ & 0.04 & 0.02 & 0.002 & 0.06 & 0.009 & 0.02 & 0.06 & 0.03 & 0.07 & 0.57 \\
\hline $\mathrm{R}^{2}$ & 0.15 & 0.23 & 0.05 & 0.25 & 0.03 & 0.27 & 0.26 & 0.21 & 0.31 & 0.28 \\
\hline
\end{tabular}

${ }^{1}$ Values in columns were not different $(P>0.05)$.

${ }^{2} \mathrm{TS}=$ total solids, anhydrous lactose; $\mathrm{TN}=$ total nitrogen $\times 6.38 ; \mathrm{NPN}=$ nonprotein nitrogen $\times 6.38 ; \mathrm{NCN}=$ noncasein nitrogen $\times 6.38 ; \mathrm{TP}$ $=$ true protein $(\mathrm{TN}-\mathrm{NPN}) ; \mathrm{SP}=$ serum protein $(\mathrm{NCN}-\mathrm{NPN}) ; \mathrm{CN}=\operatorname{casein}(\mathrm{TN}-\mathrm{NCN}) ; \mathrm{CN} \% \mathrm{TP}=100 \times \mathrm{CN} / \mathrm{TP}$.

\section{Retentate Composition}

The average retentate TN, NPN, and TP concentrations are shown in Table 3 at both the starting and limiting flux for the 3 target recirculation loop TP concentrations. To determine limiting flux as a function of recirculation loop TP concentration it was important to control the TP concentration, both as the flux was increased during a run and between replicates. The TP concentration was well controlled at the 3 recirculation loop TP levels with no detectable effect of flux on TP concentration in the recirculation loop $(P>0.05$; Table 4). The NPN concentration in the retentate increased slightly (Tables 3 and 4) from the beginning to the end of the run, from $0.05 \pm 0.003$ to $0.06 \pm 0.005 \%$, but no effect of retentate TP concentration on this increase was detected and the magnitude of increase was small.

\section{Permeate Composition}

The TN, NPN, and TP content of the MF permeates at the starting and limiting fluxes at each target recirculation loop TP concentration are shown in Table
3. No difference in TN, NPN, and TP among target recirculation loop TP concentrations was detected $(P$ $>0.05$ ). As shown in Tables 3 and 4 , the TN and TP concentration in the permeate decreased $(P<0.05)$ as flux increased and NPN increased (Table 4), but these changes did not depend on target recirculation loop TP concentration.

\section{MF Process Parameters}

Cross-Flow Velocity and Longitudinal Pressure Drop. The MF system recirculation rate was controlled to maintain a constant $\Delta \mathrm{P}$. As shown in Tables 5 and 6 , the $\Delta \mathrm{P}$ averaged $220 \mathrm{kPa}$ and no difference between target recirculation loop TP concentrations was detected $(P>0.05)$. A consequence of operating the $\mathrm{MF}$ at a constant $\Delta \mathrm{P}$ was that the cross-flow velocity decreased as recirculation loop TP concentration increased (Table 5). This is consistent with fluid mechanics, which predicts that as viscosity and density increase the cross-flow velocity will decrease when $\Delta \mathrm{P}$ is kept constant for turbulent flow (Denn, 1980).

Table 3. Mean $(\mathrm{n}=3)$ composition (expressed as a percent) of the microfiltration retentates and permeates produced at the 3 target recirculation loop true protein (TP) concentrations, 8,9 , and $10 \%$, at the starting and limiting flux using diluted $85 \%$ milk protein concentrate as a feed material for a 4 -mm ceramic membrane

\begin{tabular}{|c|c|c|c|c|c|c|c|}
\hline \multirow[b]{2}{*}{ Item } & \multirow{2}{*}{$\begin{array}{c}\text { Target TP } \\
\text { concentration }\end{array}$} & \multicolumn{3}{|c|}{ Starting flux } & \multicolumn{3}{|c|}{ Limiting flux } \\
\hline & & $\mathrm{TN}$ & NPN & $\mathrm{TP}$ & $\mathrm{TN}$ & NPN & $\mathrm{TP}$ \\
\hline \multirow[t]{5}{*}{ Retentate } & $8 \%$ & $8.25^{\mathrm{c}}$ & 0.042 & $8.22^{\mathrm{c}}$ & $8.25^{\mathrm{c}}$ & 0.059 & $8.19^{\mathrm{c}}$ \\
\hline & $9 \%$ & $9.24^{\mathrm{b}}$ & 0.047 & $9.19^{\mathrm{b}}$ & $9.23^{\mathrm{b}}$ & 0.069 & $9.16^{\mathrm{b}}$ \\
\hline & $10 \%$ & $10.12^{\mathrm{a}}$ & 0.048 & $10.07^{\mathrm{a}}$ & $10.23^{\mathrm{a}}$ & 0.067 & $10.16^{\mathrm{a}}$ \\
\hline & $\mathrm{SE}$ & 0.10 & 0.007 & 0.09 & 0.07 & 0.009 & 0.07 \\
\hline & $\mathrm{R}^{2}$ & 0.97 & 0.08 & 0.97 & 0.98 & 0.11 & 0.99 \\
\hline \multirow{5}{*}{ Permeate } & $8 \%$ & 0.79 & 0.037 & 0.75 & 0.75 & 0.048 & 0.70 \\
\hline & $9 \%$ & 0.75 & 0.036 & 0.72 & 0.70 & 0.041 & 0.66 \\
\hline & $10 \%$ & 0.79 & 0.036 & 0.75 & 0.76 & 0.041 & 0.72 \\
\hline & SE & 0.03 & 0.005 & 0.03 & 0.03 & 0.004 & 0.03 \\
\hline & $\mathrm{R}^{2}$ & 0.16 & 0.009 & 0.12 & 0.32 & 0.25 & 0.26 \\
\hline
\end{tabular}

${ }^{a-c}$ Means in the same column not sharing a common superscript differ $(P<0.05)$.

${ }^{1} \mathrm{TN}=$ total nitrogen $\times 6.38 ; \mathrm{NPN}=$ nonprotein nitrogen $\times 6.38 ; \mathrm{TP}=$ true protein $(\mathrm{TN}-\mathrm{NPN})$. 
Table 4. Analysis of variance df and type III sum of squares microfiltration retentate and permeate composition produced at the 3 target recirculation loop true protein (TP) concentrations: 8,9 , and $10 \%$ at the starting and limiting flux

\begin{tabular}{|c|c|c|c|c|c|c|c|}
\hline \multirow[b]{2}{*}{ Model term } & \multirow[b]{2}{*}{ df } & \multicolumn{3}{|c|}{ Retentate $^{1}$} & \multicolumn{3}{|c|}{ Permeate $^{1}$} \\
\hline & & $\mathrm{TN}$ & $\mathrm{NPN}$ & $\mathrm{TP}$ & $\mathrm{TN}$ & $\mathrm{NPN}$ & $\mathrm{TP}$ \\
\hline Whole model & & $11.29^{*}$ & $0.004^{*}$ & $11.18^{*}$ & $0.042^{*}$ & $0.001^{*}$ & $0.052^{*}$ \\
\hline Target TP & 2 & $11.07^{*}$ & 0.0002 & $10.98^{*}$ & 0.008 & 0.00007 & 0.008 \\
\hline Rep $(\text { target } \mathrm{TP})^{2}$ & 6 & 0.20 & $0.0019^{*}$ & 0.18 & $0.025^{*}$ & $0.00068^{*}$ & $0.033^{*}$ \\
\hline \multicolumn{8}{|l|}{ Subplot } \\
\hline Flux & 1 & 0.005 & $0.0016^{*}$ & 0.0008 & $0.0078^{*}$ & $0.00021^{*}$ & $0.011^{*}$ \\
\hline Target TP flux & 2 & 0.013 & 0.00002 & 0.014 & 0.0006 & 0.00003 & 0.0007 \\
\hline $\mathrm{R}^{2}$ & & $>0.99$ & 0.94 & $>0.99$ & 0.97 & 0.93 & 0.97 \\
\hline
\end{tabular}

${ }^{1} \mathrm{TN}=$ total nitrogen, $\mathrm{TP}=$ true protein $[\mathrm{TN}$ minus NPN].

${ }^{2}$ Used as error term to test significance of whole-plot term (target TP).

$* P<0.05$.

TMP and Flux. No difference in TMP was detected among the 3 target recirculation loop TP concentrations at the starting or limiting flux $(P>0.05)$, as shown in Table 5. As flux increased the TMP increased $(P<0.05)$ (Figure 2 and Table 7$)$ for the 3 target recirculation loop TP concentrations. The increase in flux with increasing TMP was dependent on the recirculation loop TP concentration (i.e., significant TMP $\times$ target TP interaction; Figure 2 and Table 7 ), and the flux versus TMP curves increasingly diverged for the different target TP as TMP increased (Figure 2).

Limiting Flux. Although no difference in TMP among the target recirculation loop TP concentrations was detected at the limiting flux (Table 5), the limiting flux increased $(P<0.05)$ as recirculation loop TP concentration decreased, as shown in Table 5 and Figure 2 . The significant flux by TP interaction for measured flux (Table 7) is a reflection of the same starting flux for all 3 target TP concentrations, but a different limiting flux.

The relationship between TMP and flux was explained by Darcy's law, shown in Equation 1, where viscosity used was permeate viscosity. The resistance in Equation 1 is the total resistance and includes the membrane resistance, resistance caused by membrane fouling, and concentration polarization. Initially, the increase in flux with TMP was close to linear, which indicated that not much change in total resistance occurred (Figure 2). However, the change in flux with changing TMP depended on the recirculation loop TP concentration (Table 7). This may indicate different levels of concentration polarization depending on the TP concentration in the recirculation loop (or the cross-flow velocity, which was a function of TP concentration in our work).

As shown in Figure 2, eventually larger increases in TMP were required to continue increasing the flux; according to Equation 1, this indicates an increase in membrane resistance, likely due to membrane fouling. Eventually increasing the TMP no longer increased the flux, indicating that the limiting flux had been reached (Figure 2):

$$
\text { Flux }=\frac{\text { TMP }}{\text { viscosity } \times \text { resistance }} .
$$

Table 5. Mean $(\mathrm{n}=3)$ longitudinal pressure drop $(\Delta \mathrm{P})$, cross-flow velocity, and transmembrane pressure (TMP) at the starting flux of $55 \mathrm{~kg} /$ $\mathrm{m}^{2}$ per hour and limiting flux at 8,9, and 10\% target true protein (TP) concentration in the recirculation loop when using diluted $85 \%$ milk protein concentrate as a feed material for a $4-\mathrm{mm}$ ceramic microfiltration membrane

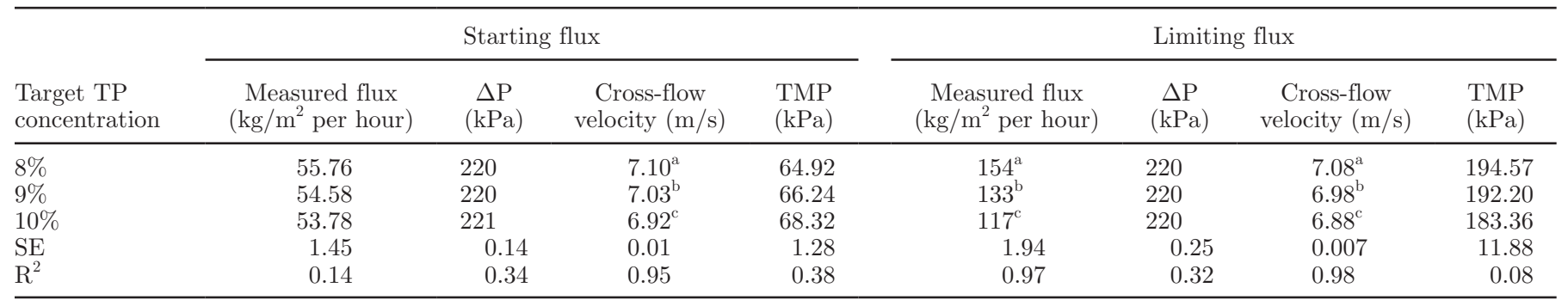

${ }^{\mathrm{a}-\mathrm{c}}$ Means within the same column not sharing a common superscript are different $(P<0.05)$. 
Table 6. ANOVA df and type III sum of squares with measured flux, longitudinal pressure drop $(\Delta \mathrm{P})$, crossflow velocity, and serum protein removal factor as the dependent variables at the 3 target recirculation loop true protein (TP) concentrations: 8,9 , and $10 \%$ at the starting and limiting flux

\begin{tabular}{lccccc}
\hline Model term & df & $\begin{array}{c}\text { Measured flux } \\
\left(\mathrm{kg} / \mathrm{m}^{2} \text { per hour }\right)\end{array}$ & $\begin{array}{c}\Delta \mathrm{P} \\
(\mathrm{kPa})\end{array}$ & $\begin{array}{c}\text { Cross-flow } \\
\text { velocity }(\mathrm{m} / \mathrm{s})\end{array}$ & $\begin{array}{c}\text { Serum protein } \\
\text { removal factor }\end{array}$ \\
\hline Whole model & & $30,967^{*}$ & $\mathrm{NS}$ & $0.112^{*}$ & $531.72^{*}$ \\
$\quad$ Target TP & 2 & $1,174^{*}$ & $\mathrm{NS}$ & $0.104^{*}$ & 7.25 \\
$\quad \begin{array}{l}\text { Rep (target TP })^{1} \\
\text { Subplot }\end{array}$ & 6 & 73.49 & $\mathrm{NS}$ & 0.002 & $392.42^{*}$ \\
$\quad$ Flux & 1 & $28,769^{*}$ & $\mathrm{NS}$ & $0.005^{*}$ & $122.83^{*}$ \\
Target TP flux & 2 & $950^{*}$ & $\mathrm{NS}$ & 0.0007 & 9.21 \\
$\mathrm{R}^{2}$ & & $>0.99$ & - & 0.99 & 0.97 \\
\hline
\end{tabular}

${ }^{1}$ Used as error term to test significance of whole-plot term (Target TP).

${ }^{2}$ Serum protein removal factor $=$ true protein in the permeate divided by serum protein concentration in the permeate portion of the microfiltration feed.

$* P<0.05$.

\section{SP Removal}

The SP removal factors are shown in Table 8 at the starting and limiting fluxes for the 3 target recirculation loop TP concentrations. No difference in SP removal factor due to recirculation loop TP concentration was detected $(P>0.05)$ at the starting or limiting flux. The SP removal factor decreased $(P<0.05)$ as the flux was increased to the limiting flux (Tables 8 and 6). However, no difference in the decrease in SP removal at the 3 different target TP concentrations was detected $(P>0.05)$. As discussed previously, as the flux approached the limiting flux, evidence of membrane fouling (increasing resistance) was noted, which likely changed the rejection characteristics of the membrane and reduced SP removal. This is consistent with the work of Gesan-Guiziou et al. (1999), where SP removal also decreased as flux was increased for the MF of skim milk.

Previous research using 4-mm-channel diameter GP membranes reported an SP removal factor close to 1

Table 7. ANOVA df and type III sum of squares for measured flux as the dependent variable at the 3 target recirculation loop true protein (TP) concentrations, 8,9 , and $10 \%$, with mean-centered transmembrane pressure (TMP) and target TP as independent variables

\begin{tabular}{lcc}
\hline Model term & df & $\begin{array}{c}\text { Measured } \\
\text { flux }\end{array}$ \\
\hline Whole model & 2 & $43,829^{*}$ \\
Target TP & 6 & $1,608^{*}$ \\
Rep (target TP) & $29.78^{*}$ \\
Subplot & & \\
TMP & 1 & $28,205^{*}$ \\
TMP $\times$ Target TP & 2 & $587^{*}$ \\
TMP $\times$ replicate $($ target TP) & 6 & $95.11^{*}$ \\
TMP $\times$ TMP & 1 & $1,732^{*}$ \\
TMP $\times$ TMP $\times$ target TP & 2 & 4.74 \\
TMP $\times$ TMP $\times$ replicate $($ target TP) & 6 & 22.46 \\
$\mathrm{R}^{2}$ & & $>0.99$ \\
\hline
\end{tabular}

${ }^{1}$ Used as error term to test significance of whole-plot term (target TP). $* P<0.05$.
(Zulewska et al., 2009), whereas in our work an SP removal factor of 0.8 was found at the starting flux. This could be due to the different cleaning procedure used in the current study. In the previous work the caustic clean took place at $80^{\circ} \mathrm{C}$ as opposed to $50^{\circ} \mathrm{C}$ in the current study, and this difference may have affected the postcleaning performance. Additional differences between the studies that might have caused the difference are the use of a diluted MPC85 as the MF feed or the higher concentration of SP in the permeate compared with skim milk.

\section{DISCUSSION}

\section{Predicting the Limiting Flux}

To predict the limiting flux, several theoretical equations have been developed (Belfort et al., 1994);

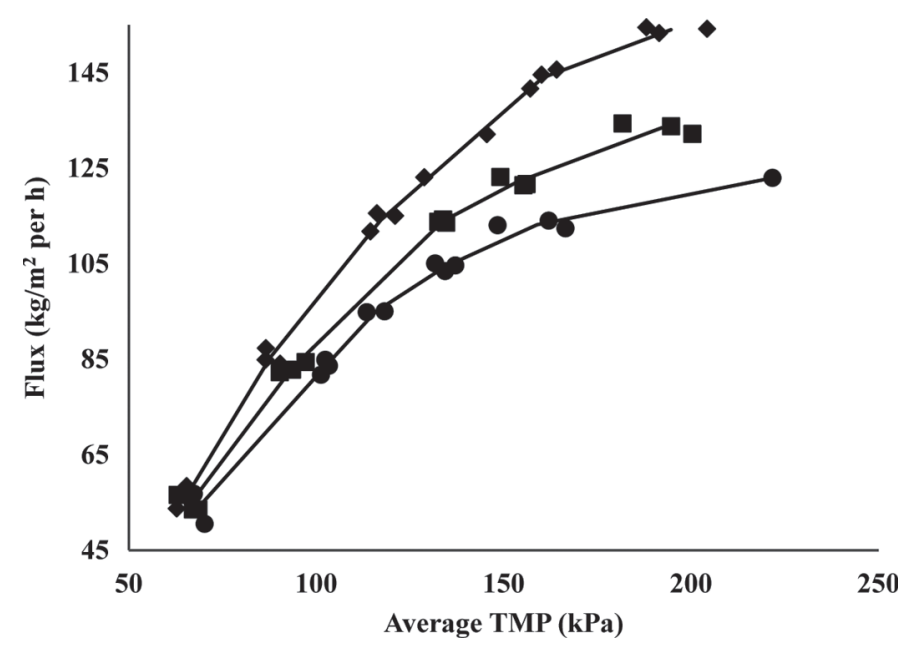

Figure 2. Plot of flux versus average transmembrane pressure (TMP) for target retentate protein concentrations of $8(\bullet), 9(\mathbf{\square})$, and $10 \%$ ) for 4-mm ceramic graded permeability membranes using a diluted $85 \%$ milk protein concentrate feed. Data from all 3 replicates are shown. 
Table 8. Mean $(\mathrm{n}=3)$ serum protein $(\mathrm{SP})$ removal factor at a flux of $55 \mathrm{~kg} / \mathrm{m}^{2}$ per hour and the limiting flux for at the target true protein (TP) recirculation loop concentrations of 8,9 and $10 \%$ when using diluted $85 \%$ milk protein concentrate as a feed material for 4-mm ceramic MF membranes $^{1}$

\begin{tabular}{lcc}
\hline $\begin{array}{l}\text { Target TP } \\
\text { concentration }\end{array}$ & $\begin{array}{c}\text { SP removal factor } \\
\text { at a flux of } \\
55 \mathrm{~kg} / \mathrm{m}^{2} \text { per hour }\end{array}$ & $\begin{array}{c}\text { SP removal factor } \\
\text { at the limiting flux }\end{array}$ \\
\hline $8 \%$ & 0.81 & 0.75 \\
$9 \%$ & 0.80 & 0.73 \\
$10 \%$ & 0.80 & 0.77 \\
$\mathrm{SE}$ & 0.030 & 0.037 \\
$\mathrm{R}^{2}$ & 0.01 & 0.06 \\
\hline
\end{tabular}

${ }^{1}$ Means within columns did not differ $(P>0.05)$.

${ }^{2} \mathrm{SP}$ removal factor $=$ true protein in the permeate divided by SP concentration in the permeate portion of the microfiltration feed.

however, Samuelsson et al. (1997) found that none of them were able to predict the limiting flux for the MF of skim milk. Samuelsson et al. (1997) developed an empirical model for the limiting flux for the MF of skim milk using ceramic membranes shown in Equation 2, where density times cross-flow velocity times channel diameter divided by retentate viscosity is the dimensionless Reynold's number:

$$
\begin{aligned}
& \text { limiting flux }=0.0025 \mathrm{~L} / \mathrm{m}^{2} \mathrm{~h} \\
& \times \frac{\text { density } \times \text { cross-flow velocity } \times \text { channel diameter }}{\text { retentate viscosity }} .
\end{aligned}
$$

Equation 2 was used to calculate the predicted flux shown in Table 9. The retentate viscosities were measured in this work, whereas the densities were estimated using an equation developed by Stepp and Smith (1991). The calculated Reynold's numbers at each recirculation loop TP concentration are also provided in Table 9.
Equation 2 underestimated the limiting flux found in our research (Table 9). There could be several reasons Equation 2 underestimated the limiting flux in our experiment, including that the MF feed in this work was diluted MPC85 as opposed to skim milk as well as the use of a different membrane system (channel diameter, length, and so on). The effect of the MF feed (skim milk or MPC85) on limiting flux warrants further investigation. In preliminary work using skim milk as the MF feed, a limiting flux of approximately $90 \mathrm{~kg} / \mathrm{m}^{2}$ per hour (at a TP concentration of $8.6 \%$ ) was found, which is much lower than the limiting flux found when diluted MPC85 was the MF feed (Figure 2). This is consistent with research by Jimenez-Lopez et al. (2008), where it was found that an increased aqueous mineral concentration increased membrane fouling in $\mathrm{MF}$ of $\mathrm{CN}$ solutions.

A plot of Reynold's number versus the limiting flux appeared linear and the slope that best fit the data points was determined using Excel 2007 (Microsoft, Redmond, WA). A better correlation between the limiting flux determined in our research and Reynold's number was found when the constant in Equation 2 was replaced with $0.00764 \mathrm{~kg} / \mathrm{m}^{2}$ per hour $\left(\mathrm{R}^{2}=0.94\right.$; Table 9). However, the predictive utility of this relationship needs to be validated. In our research, crossflow velocity, viscosity, and density were all a function of the recirculation loop TP concentration and were not varied independently and only 1 channel diameter was used.

\section{Sustainable Flux}

The limiting flux provides an upper bound on flux. A sustainable flux would be a flux that could be maintained for a long period of time, such as a production

\begin{tabular}{|c|c|c|c|c|c|c|}
\hline $\begin{array}{l}\text { Target TP } \\
\text { concentration }\end{array}$ & $\begin{array}{l}\text { Viscosity }^{1} \\
(\mathrm{~Pa} \times \mathrm{s})\end{array}$ & $\begin{array}{l}\text { Density }^{2} \\
\left(\mathrm{~kg} / \mathrm{m}^{3}\right)\end{array}$ & $\begin{array}{l}\text { Reynold's } \\
\text { number }\end{array}$ & $\begin{array}{c}\text { Limiting flux } \\
\left(\mathrm{kg} / \mathrm{m}^{2} \text { per hour }\right)\end{array}$ & $\begin{array}{c}\text { Samuelsson }^{4} \\
\text { predicted limiting } \\
\text { flux }\left(\mathrm{kg} / \mathrm{m}^{2} \text { per hour }\right)\end{array}$ & $\begin{array}{c}\text { Predicted limiting } \\
\text { flux }{ }^{5}\left(\mathrm{~kg} / \mathrm{m}^{2} \text { per hour }\right)\end{array}$ \\
\hline $8 \%$ & $0.00147^{\mathrm{c}}$ & $1,036^{\mathrm{c}}$ & $19,922^{\mathrm{a}}$ & $154^{\mathrm{a}}$ & 50 & 152 \\
\hline $9 \%$ & $0.00163^{\mathrm{b}}$ & $1.039^{\mathrm{b}}$ & $17,824^{\mathrm{b}}$ & $133^{\mathrm{b}}$ & 45 & 136 \\
\hline $10 \%$ & $0.00190^{\mathrm{a}}$ & $1,043^{\mathrm{a}}$ & $15,116^{\mathrm{c}}$ & $117^{\mathrm{c}}$ & 38 & 116 \\
\hline $\mathrm{SE}$ & 0.00002 & 0.25 & 233 & 1.94 & - & - \\
\hline $\mathrm{R}^{2}$ & 0.97 & 0.98 & 0.97 & 0.97 & - & - \\
\hline
\end{tabular}

Table 9. Prediction of limiting flux

${ }^{1}$ Viscosity measured at $50^{\circ} \mathrm{C}$.

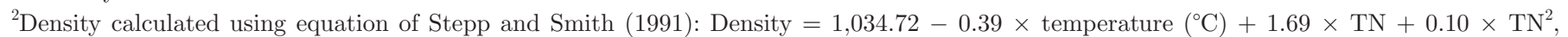
where $\mathrm{TN}=$ total nitrogen.

${ }^{3}$ Reynold's number calculated as density $\times$ cross-flow velocity $\times$ channel diameter/viscosity.

${ }^{4}$ Predicted using the equation developed by Samuelsson et al. (1997) where flux $=0.0025 \mathrm{~L} / \mathrm{m}^{2}$ per hour $\times$ Reynold's number.

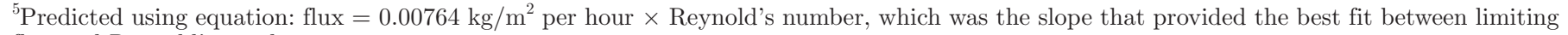
flux and Reynold's number. 


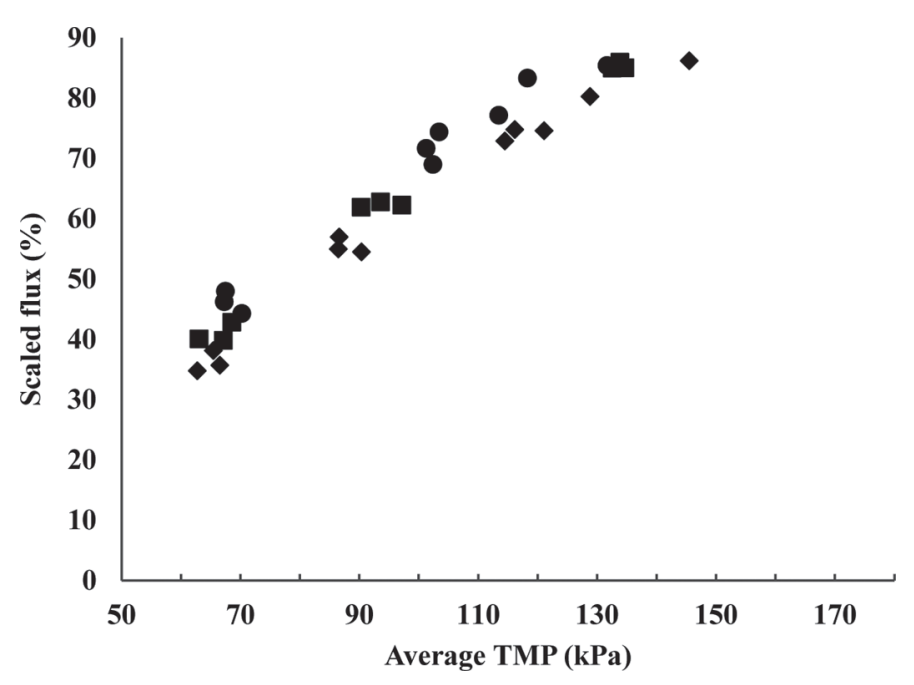

Figure 3. Plot of scaled flux versus average transmembrane pressure (TMP) for target retentate protein concentrations of $8(\bullet), 9(\boldsymbol{\square})$, and $10 \%$ (•) for 4-mm ceramic graded permeability membranes using a diluted $85 \%$ milk protein concentrate feed. Data from all 3 replicates are shown.

run. A plot of scaled flux (measured flux divided by the limiting flux at each recirculation loop TP concentration) versus TMP is shown in Figure 3. Regardless of the target recirculation loop $\mathrm{TP}$, there appears to be a similar relationship between scaled flux and TMP. Figure 3 implies that the limiting flux could be estimated for a TP concentration by operating the system at a specific TMP (which corresponds to a percentage of the limiting flux) and measuring the flux. The data in Figure 3 also suggests that a sustainable flux may be achieved by operating at a specific TMP that corresponds to a percentage of the limiting flux. This is consistent with Bacchin (2004), that the critical flux (below which no membrane fouling occurs) was twothirds of the limiting flux. In 2 runs using the 4-mm channel diameter GP membranes, with a recirculation loop TP concentration of $10 \%$, we found (data not reported) that a flux of $100 \mathrm{~kg} / \mathrm{m}^{2}$ per hour ( $85 \%$ of the limiting flux) could be maintained for over $10 \mathrm{~h}$ with an average TMP of approximately $130 \mathrm{kPa}$.

Further work is required to explore the large effect that using diluted MPC85 appeared to have on the limiting flux, but from our work it appears that the use of MPC85 as an MF feed would allow operation at much higher fluxes (and reduce the required membrane area). The relationship between recirculation loop protein concentration and limiting flux is important for the design of a MF process. Increasing the recirculation loop target TP concentration reduces the amount of MF permeate that has to be removed (to produce a specific MCC), whereas the flux affects the membrane area (or time) required (Hurt and Barbano, 2015).

\section{CONCLUSIONS}

The limiting flux decreased as TP concentration in the recirculation loop increased. The limiting flux was $154 \pm 0.3,133 \pm 0.7$, and $117 \pm 3.3 \mathrm{~kg} / \mathrm{m}^{2}$ per hour at recirculation loop TP concentrations of $8.2 \pm 0.07$, $9.2 \pm 0.04$, and $10.2 \pm 0.09 \%$, respectively. No effect of recirculation loop TP concentration on the SP removal factor was detected. However, the SP removal factor decreased from $0.80 \pm 0.02$ to $0.75 \pm 0.02$ as flux was increased from the starting flux of $55 \mathrm{~kg} / \mathrm{m}^{2}$ per hour to the limiting flux, with a similar decrease seen at all recirculation loop TP concentrations.

\section{ACKNOWLEDGMENTS}

The authors thank the Northeast Dairy Foods Research Center (Ithaca, NY) and New York State Milk Production Board (Albany, NY) for partial funding of this research. The authors also thank O-AT-KA Milk Products Cooperative (Batavia, NY) and Pall Corporation (Cortland, NY) for their support of this research. Additionally, the technical assistance of Michelle Bilotta, Sara Bova, and Chassidy Coon from the Department of Food Science at Cornell University was greatly appreciated.

\section{REFERENCES}

AOAC International. 2000. Official Methods of Analysis. 17th ed. AOAC Int., Gaithersburg, MD.

Bacchin, P. 2004. A possible link between critical and limiting flux for colloidal systems: Consideration of critical deposit formation along the membrane. J. Membr. Sci. 228:237-241.

Bacchin, P., P. Aimar, and R. W. Field. 2006. Critical and sustainable fluxes: Theory, experiments and applications. J. Membr. Sci. 281:42-69.

Barbano, D. M., V. Sciancalepore, and M. A. Rudan. 1988. Characterization of milk proteins in ultrafiltration permeate. J. Dairy Sci. 70:2655-2657.

Belfort, G., R. H. Davis, and A. L. Zydney. 1994. The behavior of suspensions and macromolecular solutions in crossflow microfiltration. J. Membr. Sci. 96:1-58.

Cheryan, M. 1998. Ultrafiltration and microfiltration handbook. Technomic Publishing Company, Inc., Lancaster, PA.

Denn, M. M. 1980. Process and Fluid Mechanics. Prentice Hall PTR, Upper Saddle River, NJ.

Garcera, D., and E. Toujas. 2002. Graded permeability macroporous support for crossflow filtration. Societe Ceramiques Techniques, assignee. USPat. No. 6,375,014B1.

Gesan-Guiziou, G., E. Boyaval, and G. Daufin. 1999. Critical stability conditions in crossflow microfiltration of skim milk: Transition to irreversible fouling. J. Membr. Sci. 158:211-222.

Hurt, E. E., and D. M. Barbano. 2015. Factors that influence the membrane area of a multi-stage microfiltration process required to produce a micellar casein concentrate. J. Dairy Sci. 98:XX-XX.

Jimenez-Lopez, A. J. E., N. Leconte, O. Dehainault, C. Geneste, L. Fromont, and G. Gesan-Guiziou. 2008. Role of milk constituents on critical conditions and deposit structure in skimmilk microfiltration $(0.1 \mu \mathrm{m})$. Separ. Purif. Tech. 61:33-43.

Luck, P. J., B. Vardhanabhuti, Y. H. Yong, T. Laundon, D. M. Barbano, and E. A. Foegeding. 2013. Comparison of functional prop- 
erties of $34 \%$ and $80 \%$ whey protein and milk serum protein concentrates. J. Dairy Sci. 96:5522-5531.

Lynch, J. M., D. M. Barbano, and J. R. Fleming. 2007. Determination of the lactose content of fluid milk by spectrophotometric enzymatic analysis using weight additions and path length adjustment. J. AOAC Int. 90:196-216.

Papadatos, A., M. Neocleous, A. M. Berger, and D. M. Barbano. 2003. Economic feasibility evaluation of microfiltration of milk prior to cheesemaking. J. Dairy Sci. 86:1564-1577.

Samuelsson, G., P. Dejmek, G. Tragardh, and M. Paulsson. 1997. Minimizing whey protein retention in cross-flow microfiltration of skim milk. Int. Dairy J. 7:237-242.

Sauer, A., and C. I. Moraru. 2012. Heat stability of micellar casein concentrates as affected by temperature and $\mathrm{pH}$. J. Dairy Sci. 95:6339-6350.
Stepp, B. L., and D. E. Smith. 1991. Effect of concentration and temperature on the density and viscosity of skim milk retentates. Milchwissenschaft 46:484-487.

US Trade Commission. 2004. Condition of competition for milk protein products in the US market. USITC Publication 3692. Accessed Feb. 2, 2015. http://www.usitc.gov/publications/332/ pub3692.pdf.

Vadi, P. K., and S. S. H. Rizvi. 2001. Experimental evaluation of a uniform transmembrane pressure crossflow microfiltration unit for the concentration of micellar casein from skim milk. J. Membr. Sci. 189:69-82.

Zulewska, J., M. Newbold, and D. M. Barbano. 2009. Efficiency of serum protein removal from skim milk with ceramic and polymeric membranes at $50^{\circ} \mathrm{C}$. J. Dairy Sci. 92:1361-1377. 